\title{
The Readiness for Successful Implementation The Accurate Accounting Information System Based on User Perception
}

\author{
$1^{\text {st }}$ A'ang Subiyakto $^{1}, 2^{\text {nd }}$ Nur Aeni Hidayah ${ }^{1}, 3^{\text {rd }}$ Latifa $_{\text {Zahra }}{ }^{1}$ \\ \{aang@uinjkt.ac.id ${ }^{1}$, nur.aeni@uinjkt.ac.id ${ }^{1}$, latifa.zahra13@mhs.uinjkt.ac.id ${ }^{1}$ \} \\ UIN Syarif Hidayatullah, Jakarta, Indonesia ${ }^{1}$
}

\begin{abstract}
The effects of the Success Information System (SIS) is Readiness of system user. The Accurate System is one of the Accounting Information Systems (IS) that assist in company bookkeeping. However, the lack of user readiness in utilizing the system resulted in the operational performance of the company is not running optimally. In addition, there is not much research related to the success information system from the user readiness side. The purpose of this research is to determine how far user readiness to the successful implementation of the Accurate system and to find out what factors influence the successful implementation of SIA Accurate using the readiness model of Technology Readiness Index (TRI) and the success of IS. Analysis techniques are PLSSEM with application tools SmartPLS 3.0. The result is 23 hypotheses tested 14 accepted or influential hypotheses and 9 hypotheses rejected.
\end{abstract}

Keywords: Accounting Information System, Accurate system, Technology Readiness Index, The Successful Information System Model, PLS SEM.

\section{Introduction}

IS are no longer viewed only as a compliment but are already a major support in the existing business processes of an organization[1]. Therefore, the role of Information and Communication Technology (ICTs) can contribute to changes in the way people work and interact in their fields[2].

Accounting Information System is a system that collects, records, stores, and processes data to generate information for decision-makers[2]. Using IS is proven to reduce costs, create faster and more efficient work processes, and offer a high level of flexibility[3].

Anyone can be an IT (information technology) or SI user, but how to implement it depends on the degree of user readiness in accepting the technology or the system[4]. And the first step in the implementation of technology is knowing the user readiness to accept the technology or system[5].

The result, the/ implementation of Accurate System found several problems from the user side and also the weaknesses of AccurateSystem itself. The example is the search engine of Accurate System, it cannot detect a keyword as a whole, the sentence can only detect the first word in a sentence. Another example is the output or the resulting report sometimes does not match the filter that has been set by the user. Therefore, some userdifficulties in learning other new cases. 
Some users who are lazy to learn cannot use the system properly. thus causing the user to suspend his work by using the old system or method then ask for the help from other users who understand to move it to Accurate System. Therefore, the degree of user readiness to use Accurate System affects success of the implementation a new technology or systems in the company.

\section{Literature Review}

\subsection{Technology Readiness}

Techhnology Readiness is defined as a tendency to embrace and use new technology to accomplish the goals of various jobs both at home and in the work place[4].The success of the implementation and the adoption of new technologies especially at an institution largely determined by factors of readiness and ability of the users[6].The Research [7]which involving 50 organizations as objects of the research stated that the low readiness levels became the cause of the failure of IS project, in particular the readiness of the user is the most dominant influence on the success of the implementation of the IS[6]. ReasearchbySheu\& Kim showed thatuser readiness factors have stronger influencethan user engagement to the success of IS project.

Technology Readiness Index was developed by [4] to measure and find out the extent to which an individual or organisation is ready to adopt an information technology. TRI is a multi-item scale which consists of 36 questions for measuring technology readiness. Scale of 36 items consists of four dimensions of beliefs component those related with technology affecting individuals in Technology Readiness. Model of TRI 2.0 consists of four dimensions, two of them are contributor and the others are inhibitor for technology adoption. The contributors are Optimism, Innovativeness, Discomfort, and Insecurity.

\subsection{Success Information System}

The success of information system is determined by how the system can be run by the users effectively, and the users feel satisfied using the system as well as how companies can take advantage of a system that they use. in 1992, Delone dan McLean developed an information system success model which consists of six element such system quality, information quality, use/ usage, user satisfaction, individual impact, and organization impact. Information System Success Model [8]is based on the process and the causal relationships of the dimensions in the model. This model does not measure to the six dimensions of measuring the success of information systems independently instead of measuring it one affects the other.

\subsection{Accurate System}

Accounting Information System is a system that collects, records, keeps, and processes data to generateinformationsfor decision makers[9].AISof Accurate is an accounting program made bythe nations. The developer system of AIS of Accurate isCPSSoft (PT. CiptaPiranti Sejahtera), and CPSSoft does not serve sales,instead of focussing in developing the program and the administration.

\section{Research Method}


In General, this research was done by applying a quantitative approach [10] and the successive research structure in accordance with its objectives is to examine the influence of the readiness against the success of the implementation Accurate System, and to test the hypothesis that deals between the influence of readiness towards the information system success.

The technique of data collection is done through the procurement survey distributed to respondents in some companies particularly VAIN Accurate users of Jakarta, with questionnaire insturment, data was analyzed statistically by using appropriate computer software. The research instrument is a questionnaire consists of 40 questions intended as a statistical data inferensial. Specifically, the researchers use a likert scale of five points from the level of "strongly disagree" (1) to "strongly agree" (5) for measurements in the questionnaire.

Population and sample in this research is the users of AIS of Accurate particularly company in Jakarta. Purposive sampling technique is deducted in this research to select parts of the population, the selected criteria are users who have experience in using AIS of Accurate. Then, the researchers determine the 125 respondents to the number of respondents based on theory with consideration of number of population, time limitations, and thus researchers pursing research area in South, East, and West Jakarta. The proposed model in this research is the one that developed by Subiyakto[11]. The model combines Technology Readiness Index (TRI) [5] and Information System Success model[8] with Input-ProccesOutput model[12][13], [14]. Readiness influence measurement model to the success of the implementation of the system consists of 9 variables(TABLE III) and 44 indicators (TABLE IV). The variables are Optimism (OPT), Innovativeness (INN), Discomfort (DIS), Insecure (INS), Information Quality (INQ), System Quality (SYQ), Service Quality (SVQ), User Satisfaction (USF), and Success Information System (SIS).

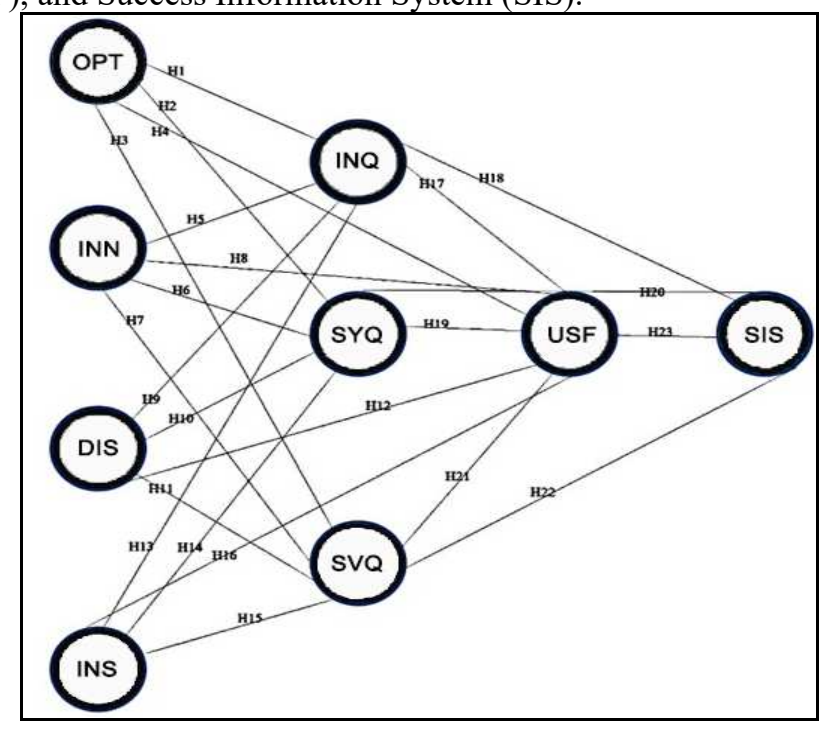

Figure 1. Purposed model

Table 1. List of The Variables [11] 


\begin{tabular}{|c|l|}
\hline Var. & \multicolumn{1}{|c|}{ Definitions } \\
\hline OPT & The degree to trust that the IS will probably happen \\
\hline INN & $\begin{array}{l}\text { The degree to perceive that the IS is the advanced degree of the } \\
\text { system }\end{array}$ \\
\hline DIS & The degree to see that the IS isnot a comfortable thing \\
\hline INS & $\begin{array}{l}\text { The degree of unbelieve that an IS integration is able to be } \\
\text { implemented properly and concerns about its potential harmful } \\
\text { consequences }\end{array}$ \\
\hline INQ & $\begin{array}{l}\text { The degree to released information of the IS } \\
\text { consistently met the requirements and expectations of the } \\
\text { users }\end{array}$ \\
\hline SYQ & The degree to explain the quality of the value of the IS \\
\hline SVQ & The degree of the quality of the IS services into its users \\
\hline USF & $\begin{array}{l}\text { The degree of the pleasure level of users during applying } \\
\text { the IS }\end{array}$ \\
\hline SIS & The achievement of the IS based on its execution planning \\
\hline
\end{tabular}

Table 2. List of The Indicators [5],[8],[15],[11]

\begin{tabular}{|c|c|}
\hline Indicators & Definitions \\
\hline $\begin{array}{l}\text { Easiness } \\
(\mathrm{OPT} 1)\end{array}$ & $\begin{array}{l}\text { The degree associated with the ability of the system } \\
\text { for providing a freedom from interruption, } \\
\text { hardship, and troubles }\end{array}$ \\
\hline $\begin{array}{l}\text { Connectivity } \\
\text { (OPT2) }\end{array}$ & $\begin{array}{l}\text { The degree associated with the ability of a system } \\
\text { toconnect successfully with other systems }\end{array}$ \\
\hline $\begin{array}{l}\text { Efficiency } \\
\text { (OPT3) }\end{array}$ & $\begin{array}{l}\text { The degree associated with the system achievement } \\
\text { to release the result compared to the resources } \\
\text { needed to get the result. }\end{array}$ \\
\hline $\begin{array}{l}\text { Effectiveness } \\
\text { (OPT4) }\end{array}$ & $\begin{array}{l}\text { The degree associated with the system ability to } \\
\text { achieve its implementation goals }\end{array}$ \\
\hline $\begin{array}{l}\text { Productivity } \\
\text { (OPT5) }\end{array}$ & $\begin{array}{l}\text { The degree associated with the system support for } \\
\text { producing the result compared to the resources } \\
\text { needed to produce the result }\end{array}$ \\
\hline $\begin{array}{l}\text { Problem Solving } \\
\text { (INN1) }\end{array}$ & $\begin{array}{l}\text { The degree associated with the system support for } \\
\text { discovery solutions to problems }\end{array}$ \\
\hline $\begin{array}{l}\text { Independence } \\
\text { (INN2) }\end{array}$ & $\begin{array}{l}\text { The degree associated withthe system ability } \\
\text { tosupport its users free from the controls } \\
\text { orinfluences }\end{array}$ \\
\hline $\begin{array}{l}\text { Challenge } \\
\text { (INN3) }\end{array}$ & $\begin{array}{l}\text { The degree associated with the system support to } \\
\text { successfully handle or get something within a } \\
\text { difficult situation or trouble }\end{array}$ \\
\hline $\begin{array}{c}\text { Stimulation } \\
\text { (INN4) }\end{array}$ & $\begin{array}{l}\text { The degree associated with the system support to } \\
\text { propose something to happen, expand, or improve }\end{array}$ \\
\hline $\begin{array}{l}\text { Competitiveness } \\
\text { (INN5) }\end{array}$ & $\begin{array}{l}\text { The degree associated with the capability of a } \\
\text { system to support the users to be more successful } \\
\text { than their rival }\end{array}$ \\
\hline $\begin{array}{l}\text { Complexity } \\
\text { (DIS1) }\end{array}$ & $\begin{array}{l}\text { The degree associated with the system features that } \\
\text { confusing or difficult to be accepted }\end{array}$ \\
\hline $\begin{array}{l}\text { Difficulty } \\
\text { (DIS2) }\end{array}$ & $\begin{array}{l}\text { The degree associated with the condition of a } \\
\text { system whichit is unable to be operated easily }\end{array}$ \\
\hline $\begin{array}{l}\text { Dependence } \\
\text { (DIS3) }\end{array}$ & $\begin{array}{l}\text { The degree associated with the condition of a } \\
\text { system which needs the other parties to perfom it }\end{array}$ \\
\hline $\begin{array}{l}\text { Lack of Support } \\
\text { (DIS4) }\end{array}$ & $\begin{array}{l}\text { The degree associated with a system which it does } \\
\text { not have any, or enough, of the support in its } \\
\text { implementation }\end{array}$ \\
\hline $\begin{array}{l}\text { Inappropriateness } \\
\text { (DIS5) }\end{array}$ & $\begin{array}{l}\text { The degree associated with the state of being } \\
\text { unsuitable }\end{array}$ \\
\hline
\end{tabular}




\begin{tabular}{|c|c|}
\hline $\begin{array}{l}\text { Failure } \\
\text { (INS1) }\end{array}$ & $\begin{array}{l}\text { The degree associated with the IS service scope } \\
\text { proper to the functional requirements }\end{array}$ \\
\hline $\begin{array}{l}\text { Threat } \\
\text { (INS2) }\end{array}$ & $\begin{array}{l}\text { The degree associated with the system condition } \\
\text { that could cause harm or dangerous }\end{array}$ \\
\hline $\begin{array}{l}\text { ReducingInteracti } \\
\text { on } \\
\text { (INS3) }\end{array}$ & $\begin{array}{l}\text { The degree associated with the system execution } \\
\text { which makes human interactions become less in } \\
\text { size,amount, and importance }\end{array}$ \\
\hline $\begin{array}{l}\text { Distraction } \\
\quad \text { (INS4) }\end{array}$ & $\begin{array}{l}\text { The degree associated with the system utilization } \\
\text { gets concern and avoid people from concentrating } \\
\text { onsomething else }\end{array}$ \\
\hline $\begin{array}{l}\text { Incredulity } \\
\text { (INS5) }\end{array}$ & $\begin{array}{l}\text { The degree associated with hesitation of the } \\
\text { system utilization }\end{array}$ \\
\hline $\begin{array}{l}\text { Accuracy } \\
\text { (INQ1) }\end{array}$ & $\begin{array}{l}\text { The feasibility degree of the result of } \\
\text { information by the system with its real standard }\end{array}$ \\
\hline $\begin{array}{l}\text { Timeliness } \\
\text { (INQ2) }\end{array}$ & $\begin{array}{l}\text { The accuracy degree of the information processing } \\
\text { ofthe IS at the planned time duration }\end{array}$ \\
\hline $\begin{array}{l}\text { Completeness } \\
\text { (INQ3) }\end{array}$ & $\begin{array}{l}\text { The degree of the resulted information by the IS } \\
\text { tobe with or without nothing missing part }\end{array}$ \\
\hline $\begin{array}{l}\text { Consistency } \\
\text { (INQ4) }\end{array}$ & $\begin{array}{l}\text { The IS trends still demonstrate the same } \\
\text { produced information within operations, services, } \\
\text { maintenance,or qualities }\end{array}$ \\
\hline $\begin{array}{l}\text { Relevance } \\
\text { (INQ5) }\end{array}$ & $\begin{array}{l}\text { The relation degree of the generatedinformation by } \\
\text { the IS with its subject matters }\end{array}$ \\
\hline $\begin{array}{l}\text { Ease-of-use } \\
\text { (SYQ1) }\end{array}$ & $\begin{array}{l}\text { The degree of a freedom by the IS from constrains, } \\
\text { difficulties, and troubles during its usages }\end{array}$ \\
\hline $\begin{array}{l}\text { Maintainability } \\
\text { (SYQ2) }\end{array}$ & $\begin{array}{l}\text { The degree associated with the easiness of the IS in } \\
\text { itsmaintenance }\end{array}$ \\
\hline $\begin{array}{l}\text { Response time } \\
\text { (SYQ3) }\end{array}$ & $\begin{array}{l}\text { The degree associated withthe amount of time it } \\
\text { takes forthe IS responding its user commands }\end{array}$ \\
\hline $\begin{array}{l}\text { Functionality } \\
\text { (SYQ4) }\end{array}$ & $\begin{array}{l}\text { The degree associated with the IS can be executed } \\
\text { appropriate to the planned requirements }\end{array}$ \\
\hline $\begin{array}{l}\text { Safety } \\
\text { (SYQ5) } \\
\end{array}$ & $\begin{array}{l}\text { The IS invulnerability degree from theunexpected } \\
\text { attacks, harms, or damages }\end{array}$ \\
\hline $\begin{array}{l}\text { Responsiveness } \\
\text { (SVQ1) }\end{array}$ & $\begin{array}{l}\text { The IS reaction degree to serve its users withinthe } \\
\text { suitable way, time and situation }\end{array}$ \\
\hline $\begin{array}{l}\text { Flexibility } \\
\text { (SVQ2) }\end{array}$ & $\begin{array}{l}\text { The IS adaptation degree to serve its users } \\
\text { proper to the required demands }\end{array}$ \\
\hline $\begin{array}{l}\text { Security } \\
\text { (SVQ3) }\end{array}$ & $\begin{array}{l}\text { The safety degree from an integrated system to } \\
\text { serveusers safely from attack, harm, or damage } \\
\text { thatunexpected }\end{array}$ \\
\hline $\begin{array}{l}\text { Functionality } \\
\text { (SVQ4) }\end{array}$ & $\begin{array}{l}\text { The degree associated with the service scope of the } \\
\text { ISappropriate to the functional requirements }\end{array}$ \\
\hline $\begin{array}{l}\text { Extension } \\
\text { (SVQ5) }\end{array}$ & $\begin{array}{l}\text { The degree associated with the IS additional } \\
\text { service scope which is more than the functional } \\
\text { requirements }\end{array}$ \\
\hline $\begin{array}{l}\text { Efficiency } \\
\text { (USF1) }\end{array}$ & $\begin{array}{l}\text { The IS user satisfaction degree based on the } \\
\text { system achievement to produce the result compared } \\
\text { to the resources needed to achieve the result }\end{array}$ \\
\hline $\begin{array}{l}\text { Effectiveness } \\
\text { (USF2) }\end{array}$ & $\begin{array}{l}\text { The IS user satisfaction degree based on the } \\
\text { system ability to fulfil the user needs for } \\
\text { achievingtheir goals }\end{array}$ \\
\hline $\begin{array}{l}\text { Flexibility } \\
\text { (USF3) }\end{array}$ & $\begin{array}{l}\text { The IS user satisfaction degree associated with the } \\
\text { adaptability of the system proper to the } \\
\text { requireddemands. }\end{array}$ \\
\hline $\begin{array}{l}\text { Overall } \\
\text { satisfaction } \\
\text { (USF4) } \\
\end{array}$ & $\begin{array}{l}\text { The IS user satisfaction degree associated with the } \\
\text { sufficiency of the overall aspect of the system }\end{array}$ \\
\hline $\begin{array}{l}\text { IS Efficiency } \\
\text { (SIS1) }\end{array}$ & $\begin{array}{l}\text { The degree associated with a comparison of the IS } \\
\text { result value and the resources needed to achievethe }\end{array}$ \\
\hline
\end{tabular}




\begin{tabular}{|c|l|}
\hline & result \\
\hline $\begin{array}{c}\text { IS Effectiveness } \\
\text { (SIS2) }\end{array}$ & $\begin{array}{l}\text { The degree associated with the capability of the } \\
\text { system sufficiency to fulfil the user needs for } \\
\text { achievingtheirgoals }\end{array}$ \\
\hline $\begin{array}{c}\text { User Satisfaction } \\
\text { (SIS3) }\end{array}$ & $\begin{array}{l}\text { The extent to which the IS helps users create value } \\
\text { fortheir business }\end{array}$ \\
\hline $\begin{array}{c}\text { Productivity } \\
\text { improvement } \\
\text { (SIS4) }\end{array}$ & $\begin{array}{l}\text { The degree associated withthe system support for } \\
\text { improving result compared to the resources needed } \\
\text { toproduce the result }\end{array}$ \\
\hline $\begin{array}{c}\text { Competitive } \\
\text { advantage } \\
\text { (SIS5) }\end{array}$ & $\begin{array}{l}\text { The degree associated with the advantaging } \\
\text { position of theintegrated IS users to compete in the } \\
\text { businesscompetitions }\end{array}$ \\
\hline
\end{tabular}

\section{The Result}

\subsection{The Results of Measurement Model Analysis}

Measurement model analysis through four stages of testing as already done by several previous researchers. The four tests are individual item reliability, internal consistency reliability, average variance extracted, and discriminant validity[16]-[21].Following an explanation, this is the results of the four tests:

\section{a. Individual Item Reliability Test}

The standardized loading factor describes the magnitude of the correlation between each measurement item (indicator) and its construct by looking at the value of the outer loading. The value of outer loading above 0.7 can be said to be good, meaning that the indicator is said to be valid as an indicator that measures the construct.

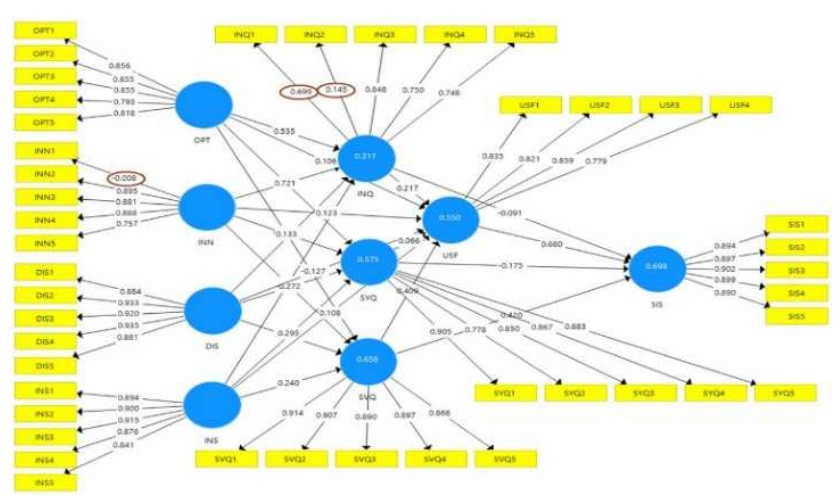

Figure 2. The result of outer loading (before some indicators deleted)

Referring to the standard value of outer loading, after going through testing on SmartPLS 3.0 , with the results deletion of the three indicators that have outer loading below 0.7 are INN1, INQ1, and INQ2. After the removal of the three indicators after being tested again using SmartPLS 3.0, the entire outer loading has fulfilled the requirements $>0.7$ individual item reliability. 


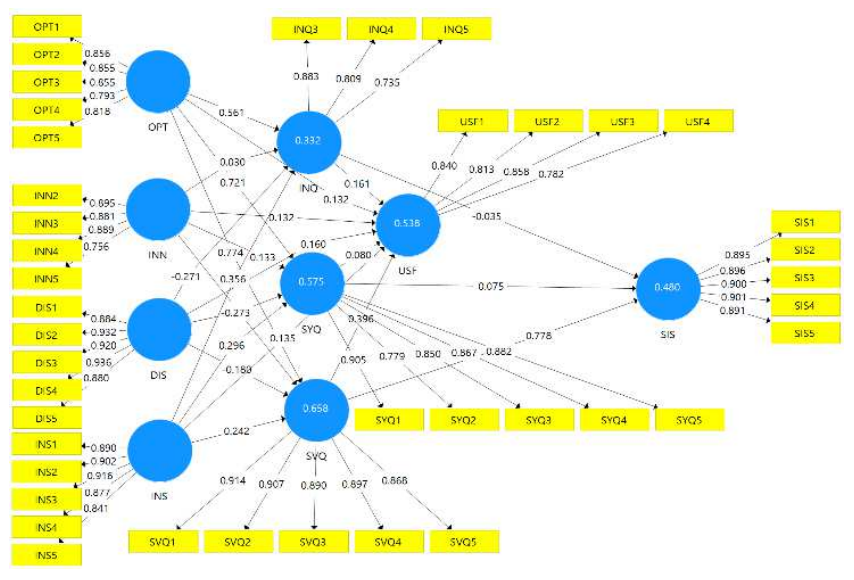

Figure 3. The result of outer loading

\section{b. Internal Consistency Reliability Test}

This test is done by looking at the results of composite reliability (CR) with a threshold above 0.7 . The results can be seen in Table 4.3 that the CR value of all variables is above 0.7 so that it is eligible and valid for use in this research model.

Table 3. The Result of The Composite Reability

\begin{tabular}{|c|c|}
\hline & Composite Reliability \\
\hline DIS & 0,960 \\
\hline INN & 0,917 \\
\hline INQ & 0,852 \\
\hline INS & 0,948 \\
\hline OPT & 0,921 \\
\hline SIS & 0,953 \\
\hline SVQ & 0,953 \\
\hline SYQ & 0,933 \\
\hline USF & 0,894 \\
\hline
\end{tabular}

\section{c. Average Variance Extracted Test}

Convergent validity testing is then performed by looking at the average variance extracted (AVE) value. This value describes the amount of variance or the diversity of manifest variables (indicators) that can be contained by latent variables (constructs). A minimum AVE value of 0.5 indicates a good convergent validity size. That is, the latent variable (construct) can explain an average of more than half the variance of the indicators. The results can be seen in Table 4.4 which shows that the AVE value of all variables is above 0.5 so that it meets the requirements for use.

\begin{tabular}{|c|c|}
\hline & Average Variance Extracted (AVE) \\
\hline DIS & 0,829 \\
\hline INN & 0,735 \\
\hline INQ & 0,658 \\
\hline
\end{tabular}




\begin{tabular}{|c|c|}
\hline INS & 0,784 \\
\hline OPT & 0,699 \\
\hline SIS & 0,804 \\
\hline SVQ & 0,802 \\
\hline SYQ & 0,736 \\
\hline USF & 0,679 \\
\hline
\end{tabular}

\section{d. Discrimant Validity Test}

This test can be done in two ways, namely by checking cross loading, first done by comparing the correlation of indicators with their constructs and other block constructs. If the correlation between indicators and their construct is higher than the correlation with other block constructs, this indicates that the construct predicts the size of their block better than the other blocks. Next, by checking the cross loading of Fornell-Lacker's, it is by comparing it with the root value of AVE, where the root value of AVE must be higher than the correlation between constructs and other constructs. The results can be seen in table 4.5 and the indicators given a yellow block on each variable have a value higher than the correlation with the other block construct.

The result shows that the root value of AVE is higher than the correlation between constructs and other constructs. So based on the results of the examination of two cross loading stages it is known that there is no problem with the discriminant validity test.

\subsection{The Results of Structure Model Analysis}

Model structure analysis is carried out through six stages of testing, namely path coefficient $(\beta)$, coefficient of determination (R2), t-test using bootstrapping method, effect size (f2), predictive relevance $\left(\mathrm{Q}^{\wedge} 2\right)$ and relative impact $(\mathrm{q} \wedge$ 2$)[16],[17],[20],[21]$. The following is an explanation of the six testing stages:

\section{a. Path Coefficient ( $\beta$ )}

This test is done by looking at the threshold value that is above 0.1 , where the path can be stated to have an influence on the model if the result of the path coefficient test value is above 0.1 . The results of the 23 hypothesis paths in this research model, 8 have insignificant influence, the results of the path coefficient test values all have values above 0.1 .

Table 4. The Result of Path Coefficient

\begin{tabular}{|c|c|}
\hline & $\beta$ \\
\hline DIS -> INQ & $-0,271$ \\
\hline DIS -> SVQ & $-0,180$ \\
\hline DIS -> SYQ & $-0,273$ \\
\hline DIS -> USF & $-0,159$ \\
\hline INN -> INQ & $-0,030$ \\
\hline INN -> SVQ & 0,129 \\
\hline INN -> SYQ & 0,133 \\
\hline INN -> USF & 0,129 \\
\hline INQ -> SIS & $-0,157$ \\
\hline INQ -> USF & 0,160 \\
\hline INS -> INQ & 0,356 \\
\hline INS -> SVQ & 0,242 \\
\hline INS -> SYQ & 0,296 \\
\hline INS -> USF & 0,137 \\
\hline
\end{tabular}




\begin{tabular}{|c|c|}
\hline OPT -> INQ & 0,561 \\
\hline OPT -> SVQ & 0,774 \\
\hline OPT -> SYQ & 0,721 \\
\hline OPT -> USF & 0,132 \\
\hline SVQ -> SIS & 0,437 \\
\hline SVQ -> USF & 0,401 \\
\hline SYQ -> SIS & $-0,152$ \\
\hline SYQ -> USF & 0,075 \\
\hline USF -> SIS & 0,686 \\
\hline
\end{tabular}

\section{b. The coefficient of Determination $\left(\mathbf{R}^{2}\right)$}

This test is carried out to explain variants of each endogenous target variable (variables considered to be influenced by other variables in the model) with a measurement standard of about 0.670 as strong, about 0.333 moderate, and 0.190 or below indicating a weak variant level [16]-[18], [20].The result shows that R2 of Information Quality (INQ) has a value of $0.332, \mathrm{R}^{2}$ of Success Information S (SIS) has a value of $0.708, \mathrm{R}^{2}$ of Service Quality (SVQ) has a value of $0.658, \mathrm{R}^{2}$ of System Quality (SYQ) has a value of 0.575 and $\mathrm{R}^{2}$ from User Satisfaction (USF) has a value of 0.536. It can be interpreted that Optimism (OPT), Innovativeness (INN), Discomfort (DIS), Insecurity (INS) explained in a moderate (33.2\%) variant of INQ, then explained strongly (70.8\%) variants of SIS , then explained moderately $(65.8 \%)$ variants of SVQ, then explained moderately $(57.5 \%)$ variants of SYQ. On the other hand, INQ, SVQ, and SYQ explained moderately (53.6\%) variants of USF.

Table 5. The Result of Coefficient ogDetermination

\begin{tabular}{|c|c|}
\hline Endogen Variable & R Square \\
\hline INQ & 0,332 \\
\hline SIS & 0,708 \\
\hline SVQ & 0,658 \\
\hline SYQ & 0,575 \\
\hline USF & 0,536 \\
\hline
\end{tabular}

\section{c. T-test}

This test is carried out using a bootstrapping method, using a two-tailed test with a significance level of $5 \%(0.05)$ to test the research hypotheses. This hypothesis will be accepted if it has a t-test greater than 1.96 [16]-[18], [20]. The other level of significance is $10 \%$ will be accepted if it has a t-test of $1.65[22]$. 


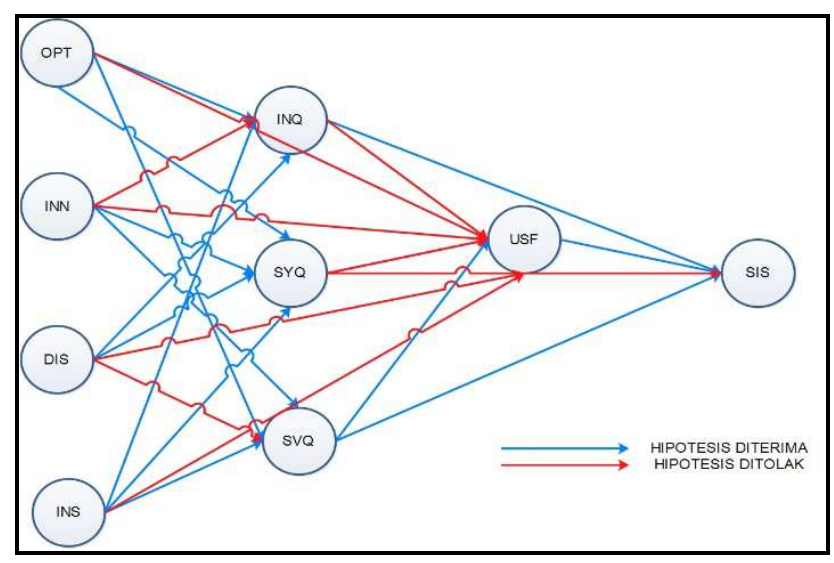

Figure 4. The result of t-test

above shows that there are 14 of the 23 hypotheses received and the rest are rejected. Following an explanation this is the results of the t-test :

Table 6. The Result of T-test

\begin{tabular}{|c|c|}
\hline Dependen ->Independen & T-test \\
\hline DIS -> INQ & 1,929 \\
\hline DIS -> SVQ & 1,626 \\
\hline DIS - SYQ & 2,181 \\
\hline DIS -> USF & 1,518 \\
\hline INN -> INQ & 0,254 \\
\hline INN -> SVQ & 1,792 \\
\hline INN -> SYQ & 1,811 \\
\hline INN -> USF & 1,450 \\
\hline INQ - > SIS & 2,123 \\
\hline INQ -> USF & 1,254 \\
\hline INS -> INQ & 2,547 \\
\hline INS -> SVQ & 2,527 \\
\hline INS - SYQ & 2,668 \\
\hline INS -> USF & 1,433 \\
\hline OPT -> INQ & 7,128 \\
\hline OPT -> SVQ & 16,486 \\
\hline OPT -> SYQ & 14,434 \\
\hline OPT -> USF & 0,993 \\
\hline SVQ -> SIS & 3,371 \\
\hline SVQ -> USF & 2,412 \\
\hline SYQ -> SIS & 1,107 \\
\hline SYQ -> USF & 0,397 \\
\hline USF -> SIS & 7,666 \\
\hline
\end{tabular}

\section{d. Effect Size (f $\mathbf{f}^{\mathbf{2}}$}

At this stage testing was conducted to determine the effect of certain variables on other variables in the structure of the model with a threshold value of about 0.02 for small influences, 0.15 for medium, and 0.35 for large influences. Calculated using the following formula. 
Note ;

$$
f^{2}=\frac{R_{\text {inchided }}^{2}-R_{\text {exchuded }}^{2}}{1-R_{\text {included }}^{2}}
$$

$R_{\text {sncluded }}^{2}$ : The value obtained when the exogenous construct is entered into the model.

$R_{\text {exrialed }}^{2}$ : The value obtained when the exogenous construct is removed from the model.

The results of testing are the 23 pathways in this study. 4 lanes have a big influence and 19 other lanes have little effect.

\section{e. Predictive Relevance $\left(Q^{2}\right)$}

This test is carried out by the blindfolding method to provide evidence that certain variables used in the model have predictive relevance with other variables in the model with a measurement threshold above zero[16], [17], [20].

Table 7. The Result of Q-Ssquare

\begin{tabular}{|c|c|}
\hline Endogen Variable & Q Square \\
\hline INQ & 0,201 \\
\hline SIS & 0,525 \\
\hline SVQ & 0,486 \\
\hline SYQ & 0,388 \\
\hline USF & 0,323 \\
\hline
\end{tabular}

\section{f. Relative Impact $\left(q^{2}\right)$}

This test is carried out by the blindfolding method to measure the relative influence of a predictive linkage of a particular variable with other variables with a threshold value of about 0.02 for small influences, 0.15 for medium / medium influence, and 0.35 for large influences [17]. The formula used for calculating $\mathrm{q}^{2}$ is as follows:

$$
\mathrm{q}^{2}=\frac{Q^{\mathrm{n}} \text { inchude }-Q^{\mathrm{n}} \text { sxclude }}{1-Q^{\mathrm{2}} \text { inelude }}
$$

The results are 3 pathways have a large value, 1 has a moderate influence and 19 other pathways have little effect.

\section{Conclusion}

The result has known the user readiness in the success of Accurate System implementation and what factors influence the success of Accurate System based on user perspective in several Jakarta companies.Indirectly, this research can be used as a measure of the readiness of users to use the system. so that it can be used as a reference for system development.In this study, 3 indicators were eliminated from 44 indicators. the eliminated indicators are INN1, INQ1, and INQ2. From these results, researchers assume that the removal of the indicator occurs due to the lack of precise instrument items.

Unacceptable 9 of the 23 hypotheses are OPT $\rightarrow$ USF, INN $\rightarrow$ INQ, INN $\rightarrow$ USF, DIS $\rightarrow \mathrm{SVQ}, \mathrm{DIS} \rightarrow \mathrm{USF}, \mathrm{INS} \rightarrow \mathrm{USF}, \mathrm{INQ} \rightarrow \mathrm{USF}, \mathrm{SYQ} \rightarrow \mathrm{USF}$ and SYQ $\rightarrow$ SIS. Differences findings of this study with previous research are influenced by several factors, including the 
differences in the object, samples and research instruments.Received 14 hypotheses ie OPT $\rightarrow$ $\mathrm{INQ}, \mathrm{OPT} \rightarrow$ SYQ, OPT $\rightarrow$ SVQ, INN $\rightarrow$ SYQ, INN $\rightarrow$ SVQ, DIS $\rightarrow$ INQ, DIS $\rightarrow$ SYQ, $\mathrm{INS} \rightarrow \mathrm{INQ}$, INS $\rightarrow$ SYQ, INS $\rightarrow$ SVQ, INQ $\rightarrow$ SIS, SVQ $\rightarrow$ USF, SVQ $\rightarrow$ SIS, USF $\rightarrow$ SIS. So, there are several influences that occur between the user readiness with success information systems in several Jakarta companies.

Acknowledgements. This paper in conjuction with the 1st International Conference On Islam, Science, And Technology (ICONIST) 2018, Malang, East Java

\section{References}

[1] T. Sutabri, Analisis Sistem Informasi. Jakarta: CV.Andi Offset, 2004.

[2] C. J. Patel, V. S. Gali, D. V Patel, and R. D. Parmar, "The effects of information and communication technologies ( ICTs ) on higher education: From objectivism to social constructivism," J. Vocat. Tech. Educ., vol. 3, no. November, pp. 113-120, 2011.

[3] V. Arvidsson, J. Holmström, and K. Lyytinen, "Information systems use as strategy practice: A multi-dimensional view of strategic information system implementation and use," J. Strateg. Inf. Syst., vol. 23, no. 1, pp. 45-61, 2014.

[4] A. Parasuraman, "Technology Readiness Index (TRI) A Multiple-item Scale to Measure Readiness Embrace New Technologies," J. Serv. Reasearch, vol. 2, no. 4, 2000.

[5] A. Parasuraman and C. L. Colby, "An Updated and Streamlined Technology Readiness Index: TRI 2.0," J. Serv. Res., vol. 18, no. 1, pp. 59-74, 2015.

[6] Jogiyanto, Model Kesuksesan Sistem Teknologi Informasi. Yogyakarta: Andi, 2007.

[7] M. Sheu and H. Kim, "User Readiness for IS Development: An Examination of 50 Cases," Syst. Res. Behav. Sci., vol. 8, no. 3, pp. 27-42, 2008.

[8] W. H. Delone and E. R. McLean, "The DeLone and McLean model of information systems success: A ten-year update," J. Manag. Inf. Syst., vol. 19, no. 4, pp. 9-30, 2003.

[9] M. B. Romney and P. J. Steinbart, "Accounting Information Systems (12th Edition).," Account. Inf. Syst., pp. 1-67, 2012.

[10] J. W. Creswell, "Research Design: Qualitative, Quantitative and Mixed Method Aproaches," SAGE Publ., pp. 203-223, 2017.

[11] A. Subiyakto, "Development of the Readiness and Success Model for Assessing the Information System Integration The author version of the presented paper ( In publishing ) Development of the Readiness and Success Model for Assessing the Information System Integration," in International Conference on Science and Technology (ICOSAT), 2017, no. September.

[12] A. Subiyakto and A. R. Ahlan, "Implementation of Input-Process-Output Model for Measuring Information System Project Success," TELKOMNIKA Indones. J. Electr. Eng., vol. 12, no. 7, pp. 5603-5612, 2014.

[13] A. Subiyakto, A. R. Ahlan, M. Kartiwi, and H. T. Sukmana, "Influences of the Input Factors towards Success of An Information System Project," TELKOMNIKA (Telecommunication Comput. Electron. Control., vol. 13, no. 2, p. 686, 2015.

[14] A. Subiyakto, A. R. Ahlan, M. Kartiwi, and S. J. Putra, "Measurement of the information system project success of the higher education institutions in Indonesia: a pilot study," Int. J. Bus. Inf. Syst., vol. 23, no. 2, pp. 229-247, 2016.

[15] M. M. Al Debei, D. Jalal, and E. Al Lozi, Measuring web portals success: a respecification and validation of the DeLone and McLean information systems success model, vol. 14, no. 1. 2013. 
[16] B. W. Afthanorhan and W. M. Asyraf, "A comparison of partial least square structural equation modeling (PLS-SEM) and covariance based structural equation modeling (CB-SEM) for confirmatory factor analysis," Int. J. Eng. Sci. Innov. Technol., vol. 2, no. 5, pp. 198-205, 2013.

[17] J. F. Hair, M. Sarstedt, C. M. Ringle, and J. A. Mena, "An assessment of the use of partial least squares structural equation modeling in marketing research," J. Acad. Mark. Sci., vol. 40, no. 3, pp. 414-433, 2012.

[18] C. M. Ringle, D. da Silva, and D. Bido, Structural equation modeling with the SmartPLS. 2015.

[19] A. Subiyakto, A. R. Ahlan, S. J. Putra, and M. Kartiwi, "Validation of Information System Project Success Model: A Focus Group Study,” SAGE Open, vol. 5, no. 2, pp. 1-14, 2015.

[20] K. K. K. Wong, "Partial Least Squares Structural Equation Modeling (PLS-SEM) Techniques Using SmartPLS,” Mark. Bull., vol. 24, no. 1, pp. 1-32, 2013.

[21] S. Yamin and H. Kurniawan, Generasi Baru Mengolah Data Penelitian dengan Partial Least Square Path Modeling: Aplikasi dengan software XLSTAT, SmartPLS, dan Visual PLS. Edisi 1. Jakarta: Salemaba Infotek, 2011.

[22] J. F. Hair, C. M. Ringle, and M. Sarstedt, "PLS-SEM: Indeed a Silver Bullet," J. Mark. Theory Pract., vol. 19, no. 2, pp. 139-152, 2011. 